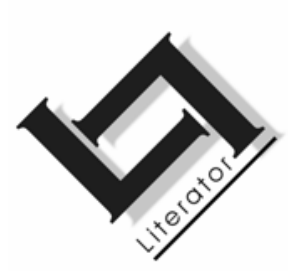

\title{
Identificative copulatives in Southern Ndebele: evidence for diachronic postulations in Zulu ${ }^{1}$
}

\author{
Lionel Posthumus \\ Department of African Languages \\ University of Johannesburg \\ AUCKLAND PARK \\ E-mail: lionelp@uj.ac.za
}

\begin{abstract}
Identificative copulatives in Southern Ndebele: evidence for diachronic postulations in Zulu

Southern Ndebele is the language with the smallest number of speakers of all eleven official languages of South Africa. It is thus not surprising that there is no comprehensive description of the copulatives of this language. This article offers an exposition of the grammatical structure of the identificative copulatives of Southern Ndebele. The basic grammatical structure of the copulatives of this language is very similar to that of Zulu. However, the unfailing occurrence of a copulative verb stem "-si" in all negative stative copulatives is an outstanding characteristic of Southern Ndebele. The occurrence of this copulative verb stem in Southern Ndebele offers the strongest language external evidence (in support of language internal evidence) of the underlying negative stative copulative of Zulu as being "-si" as well. The identificative copulative particle that occurs as "ngi" with the pronouns of all persons and noun classes as complement in Southern Ndebele, also serves as language external evidence for the postulation of the identificative copulative particle of Zulu as "ngi". Zulu grammarians postulate this identificative copulative particle of Zulu
\end{abstract}

1 I am grateful to Ms. Nomsebenzi Skosana for verifying the Southern Ndebele data and to Prof. Robert Botne of Bloomington University for valuable comments on an earlier draft of this article. 
as "nga", "ngu" or even "ng". It is argued in this article that the identificative copulative particle of Zulu is indeed "ngi".

\section{Opsomming}

\section{Identifiserende kopulatiewe in Suid-Ndebele: ondersteuning vir diachroniese postulerings in Zoeloe}

Suid-Ndebele is die taal met die kleinste getal sprekers van die elf amptelike tale van Suid-Afrika. Dit is daarom nie verrassend dat daar geen omvattende beskrywing van die kopulatiewe van hierdie taal bestaan nie. Hierdie artikel bied 'n uiteensetting van die grammatiese struktuur van die identifiserende kopulatiewe van Suid-Ndebele. Die basiese grammatiese struktuur van die kopulatiewe van hierdie taal stem baie ooreen met dié van Zoeloe. Die reëlmatige voorkoms van die kopulatiewe werkwoordstam "-si" in alle negatiewe statiewe kopulatiewe is egter 'n uitstaande kenmerk van Suid-Ndebele. Die voorkoms van hierdie kopulatiewe werkwoordstam in Suid-Ndebele is die sterkste taaleksterne bewys (in aansluiting by die taalinterne bewyse) vir die postulering van 'n onderliggende negatiewe statiewe kopulatiewe werkwoordstam "-si" vir Zoeloe. Die identifiserende kopulatiewe partikel wat in Suid-Ndebele as "ngi" realiseer, saam met die voornaamwoorde van eerste en tweede persoon en die naamwoordklasse as komplement, dien ook as taaleksterne bewys vir die postulering van die identifiserende kopulatiewe partikel van Zoeloe as "ngi". Zoeloe-grammatici postuleer hierdie identifiserende kopulatiewe partikel van Zoeloe as "nga", "ngu" en selfs "ng". In hierdie artikel word aangevoer dat die identifiserende kopulatiewe partikel van Zoeloe inderdaad "ngi" is.

\section{Introduction}

Southern Ndebele is the least spoken and least studied of the eleven official languages of South Africa. It is thus not surprising that the copulatives (probably the most perplexing grammatical structures in the Bantu languages) of Southern Ndebele have not been documented exhaustively. In some respects the identificative copulatives of Southern Ndebele are similar to those of Zulu. The Southern Ndebele copulatives have, nevertheless, some unique characteristics.

\section{Aims}

The article aims to:

- offer an overview of the copulatives of Southern Ndebele; 
- use the language data from Southern Ndebele to support the postulation of the identificative copulative particle ${ }^{2}$ of Zulu as ngi; and

- illustrate how the language data of Southern Ndebele (as external language evidence) support the postulation of a stative negative copulative verb stem -si for all stative copulatives of Zulu. (The unfailing occurrence of this copulative verb stem in all subcategories of the stative copulative in Southern Ndebele offers the strongest proof, on the comparative level, for the justification of the postulation of an underlying negative stative copulative verb stem *-si for Zulu where this copulative verb stem has a very limited occurrence.)

\section{Classification of copulatives in Southern Ndebele}

Following Welmers (1973:328), the copulatives of Southern Ndebele are subcategorised into four subtypes, namely the identificative, associative, descriptive and locative copulatives. These copulative types can occur in either the inchoative or stative form. The inchoative and stative categories are in binary opposition. In this article the focus will be on the identificative copulatives.

The scheme below represents a summary of the patterns of the identificative copulatives of Southern Ndebele in the indicative mood. The following abbreviations and symbols are used in the tables below:

- $\quad \#=$ a scientific word boundary;

- $\varnothing=$ a zero morpheme occurs in this slot;

- $\quad$ subj agr = subject agreement morpheme;

2 Although most Bantu grammarians use the term copula to denote the element (which occurs as ngi (or $y i$ ) in Zulu) that distinguishes the identificative copulatives from the other types of copulative, the term identificative copulative particle is used instead. The term copula is avoided, because it refers to the verb to be. Consider for example Longman Concise English Dictionary (1987:307), Oxford Advanced Learner's Dictionary (1995:257), The Collins paperback English Dictionary (1986:190) and Pei and Gaynor (1954:48). The identificative copulative particle is not a verb. It can actually co-occur with the copulative verb stems - $b a$, - $b i$ and -si in Southern Ndebele, as is evident from the examples in this article. These language forms, furthermore, conform to the separability test for word identification developed by Van Wyk (1958 and 1968) and applied to Northern Sotho by Lombard et al. (1985:12-13) and are thus regarded as particle words. 
- ident cop = identificative copulative particle;

- $\mathrm{N}=$ noun;

- $\mathrm{ku}-=$ the impersonal subject agreement morpheme

- Affirmative patterns of the identificative copulatives

\begin{tabular}{|c|c|c|}
\hline & \multicolumn{2}{|c|}{ With a noun as complement } \\
\hline & Stative & Inchoative \\
\hline \multicolumn{3}{|c|}{ Personal copulative forms } \\
\hline Structure & $\begin{array}{l}\text { 1. subj agr \# N with low tone } \\
\text { true prefix only } \\
\text { 2. subj agr \# (redupl /CV/ of } \\
\text { true prefix) }+\mathrm{N} \text { with true } \\
\text { prefix only } \\
\text { 3. subj agr \# (ident cop ngi) \# N } \\
\text { from class 1a } \\
\text { 4. subj agr \# (ident cop yi) \# N } \\
\text { from class } 9\end{array}$ & $\begin{array}{l}\text { 1. subj agr }+ \text { ba \# } N \text { with low tone } \\
\text { true prefix only } \\
\text { 2. subj agr }+ \text { ba \# (redupl /CV/ of } \\
\text { true prefix) }+\mathrm{N} \text { with true } \\
\text { prefix only } \\
\text { 3. subj agr }+ \text { ba \# (ident cop ngi) \# } \\
\mathrm{N} \text { from class } 1 \mathrm{a} \\
\text { 4. subj agr }+ \text { ba \# (ident cop } \mathrm{y}) \# \mathrm{~N} \\
\text { from class } 9\end{array}$ \\
\hline Examples & $\begin{array}{l}\text { 1. nibatjhumayeli } \\
\text { 2. nibabantu } \\
\text { 3. unguVusi } \\
\text { 4. siyinja }\end{array}$ & $\begin{array}{l}\text { 1. niba batjhumayeli } \\
\text { 2. niba babantu } \\
\text { 3. uba ngugogo } \\
\text { 4. siba yinja }\end{array}$ \\
\hline \multicolumn{3}{|c|}{ Impersonal copulative forms } \\
\hline Structure & $\begin{array}{l}\text { 1. subj agr \# N with low tone } \\
\text { true prefix only } \\
\text { 2. subj agr \# (redupl /CV/ of } \\
\text { true prefix) + N with true } \\
\text { prefix only } \\
\text { 3. subj agr \# (ident cop ngi) \# N } \\
\text { from class 1a } \\
\text { 4. subj agr \# (ident cop yi) \# N } \\
\text { from class } 9\end{array}$ & $\begin{array}{l}\text { 1. ku + ba \# N with low tone true } \\
\text { prefix only } \\
\text { 2. ku + ba \# (redupl /CV/ of true } \\
\text { prefix) }+N \text { with true prefix only } \\
\\
\text { 3. ku + ba \# (ident cop ngi) \# N } \\
\text { from class } 1 \text { a } \\
\text { 4. ku + ba \# (ident cop yi) \# N from } \\
\text { class } 9\end{array}$ \\
\hline Examples & $\begin{array}{l}\text { 1. màqanda } \\
\text { 2. mumukhwa } \\
\text { 3. nguVusi } \\
\text { 4. yinja }\end{array}$ & $\begin{array}{l}\text { 1. kuba màqanda } \\
\text { 2. kuba mumukhwa } \\
\text { 3. kuba ngugogo } \\
\text { 4. kuba yinja }\end{array}$ \\
\hline
\end{tabular}




\begin{tabular}{|c|c|c|}
\hline & \multicolumn{2}{|c|}{ With an emphatic pronoun as complement } \\
\hline & Stative & Inchoative \\
\hline \multicolumn{3}{|c|}{ Personal copulative forms } \\
\hline Structure & $\begin{array}{l}\text { 1. subj agr \# (ident cop ngi) \# } \\
\text { shortened pronoun } \\
\text { 2. subj agr \# (ident cop ngu) \# } \\
\text { shortened pronoun }\end{array}$ & $\begin{array}{l}\text { 1. subj agr + ba \# (ident cop ngi) \# } \\
\text { shortened pronoun } \\
\text { 2. subj agr + ba \# (ident cop ngu) \# } \\
\text { shortened pronoun }\end{array}$ \\
\hline Examples & $\begin{array}{l}\text { 1. ningibo(na) } \\
\text { 2. nginguye( } \mathrm{na})\end{array}$ & $\begin{array}{l}\text { 1. niba ngibo(na) } \\
\text { 2. ngiba nguye(na) }\end{array}$ \\
\hline \multicolumn{3}{|c|}{ Impersonal copulative forms } \\
\hline Structure & $\begin{array}{l}\text { 1. } \varnothing \# \text { (ident cop ngi) \# } \\
\text { shortened pronoun } \\
\text { 2. } \varnothing \# \text { (ident cop ngu) \# } \\
\text { shortened pronoun }\end{array}$ & $\begin{array}{l}\text { 1. ku + ba \# (ident cop ngi) \# } \\
\text { shortened pronoun } \\
\text { 2. ku + ba \# (ident cop ngu) \# } \\
\text { shortened pronoun }\end{array}$ \\
\hline Examples & $\begin{array}{l}\text { 1. ngithi(na) } \\
\text { 2. nguye(na) }\end{array}$ & $\begin{array}{l}\text { 1. kuba ngibo(na) } \\
\text { 2. kuba nguye(na) }\end{array}$ \\
\hline
\end{tabular}

- $\quad$ Negative patterns

\begin{tabular}{|c|c|c|}
\hline & \multicolumn{2}{|c|}{ With a noun as complement } \\
\hline & Stative & Inchoative \\
\hline \multicolumn{3}{|c|}{ Personal copulative forms } \\
\hline Structure & $\begin{array}{l}\text { 1. a }+ \text { subj agr }+ \text { si \# } N \text { with low } \\
\text { tone true prefix only } \\
\text { 2. a }+ \text { subj agr }+ \text { si \# (redupl } \\
\text { /CV/ of true prefix) }+N \text { with } \\
\text { true prefix only } \\
\text { 3. a + subj agr }+ \text { si \# (ident cop } \\
\text { ngi) \# N from class } 1 \text { a } \\
\text { 4. a + subj agr + si \# (ident cop } \\
\text { yi) \# N from class } 9\end{array}$ & $\begin{array}{l}\text { 1. a }+ \text { subj agr }+ \text { bi \# } N \text { with low } \\
\text { tone true prefix only } \\
\text { 2. } a+\text { subj agr }+ \text { bi \# (redupl /CV/ } \\
\text { of true prefix }+N \text { with } \\
\text { true prefix only } \\
\text { 3. a }+ \text { subj agr }+ \text { bi \# (ident cop ngi) } \\
\text { \# } N \text { from class } 1 a \\
\text { 4. a }+ \text { subj agr }+ \text { bi \# (ident cop yi) } \\
\# N \text { from class } 9\end{array}$ \\
\hline Examples & $\begin{array}{l}\text { 1. anisi batjhumayeli } \\
\text { 2. anisi babantu } \\
\text { 3. awusi nguVusi } \\
\text { 4. asisi yinja }\end{array}$ & $\begin{array}{l}\text { 1. anibi batjhumayeli } \\
\text { 2. anibi babantu } \\
\text { 3. awubi ngugogo } \\
\text { 4. asibi yinja }\end{array}$ \\
\hline
\end{tabular}




\section{Impersonal copulative forms}

\begin{tabular}{|c|c|c|}
\hline Structure & $\begin{array}{l}\text { 1. a }+ \text { ku }+ \text { si \# N with low tone } \\
\text { true prefix only } \\
\text { 2. } a+k u+s i \# \text { (redupl /CV/ of } \\
\text { true prefix) }+N \text { with true prefix } \\
\text { only } \\
\text { 3. a }+ \text { ku }+ \text { si \# (ident cop ngi) \# } \\
\mathrm{N} \text { from class 1a } \\
\text { 4. a }+ \text { ku }+ \text { si \# (ident cop yi) \# N } \\
\text { from class } 9\end{array}$ & $\begin{array}{l}\text { 1. } a+k u+b i \# N \text { with low tone } \\
\text { true prefix only } \\
\text { 2. } a+k u+b i \# \text { (redupl /CV/ of } \\
\text { true prefix) }+\mathrm{N} \text { with true prefix } \\
\text { only } \\
\text { 3. } a+k u+b i \# \text { (ident cop ngi) \# N } \\
\text { from class } 1 a \\
\text { 4. } a+k u+b i \text { (ident cop yi) \#N } \\
\text { from class } 9\end{array}$ \\
\hline Examples & $\begin{array}{l}\text { 1. akusi maqanda } \\
\text { 2. akusi mumukhwa } \\
\text { 3. akusi nguVusi } \\
\text { 4. akusi yinja }\end{array}$ & $\begin{array}{l}\text { 1. akubi maqanda } \\
\text { 2. akubi mumukhwa } \\
\text { 3. akubi ngugogo } \\
\text { 4. akubi yinja }\end{array}$ \\
\hline
\end{tabular}

With an emphatic pronoun as complement

\begin{tabular}{|c|c|c|}
\hline & Stative & Inchoative \\
\hline \multicolumn{3}{|c|}{ Personal copulative forms } \\
\hline Structure & $\begin{array}{l}\text { 1. a + subj agr + si \# (ident cop } \\
\text { ngi) \# shortened pronoun } \\
\text { 2. a + subj agr + si \# (ident cop } \\
\text { ngu) \# shortened pronoun }\end{array}$ & $\begin{array}{l}\text { 1. a + subj agr }+ \text { bi \# (ident cop ngi) } \\
\text { \# shortened pronoun } \\
\text { 2. a + subj agr + bi \# (ident cop } \\
\text { ngu) \# shortened pronoun }\end{array}$ \\
\hline Examples & $\begin{array}{l}\text { 1. anisi ngibo(na) } \\
\text { 2. angisi nguye(na) }\end{array}$ & $\begin{array}{l}\text { 1. anibi ngibo(na) } \\
\text { 2. angibi nguye(na) }\end{array}$ \\
\hline \multicolumn{3}{|c|}{ Impersonal copulative forms } \\
\hline Structure & $\begin{array}{l}\text { 1. a }+ \text { ku }+ \text { si \# (ident cop ngi) \# } \\
\text { shortened pronoun } \\
\text { 2. a }+ \text { ku }+ \text { si \# (ident cop ngu) \# } \\
\text { shortened pronoun }\end{array}$ & $\begin{array}{l}\text { 1. a + ku + bi \# (ident cop ngi) \# } \\
\text { shortened pronoun } \\
\text { 2. a }+ \text { ku }+ \text { bi \# (ident cop ngu) \# } \\
\text { shortened pronoun }\end{array}$ \\
\hline Examples & $\begin{array}{l}\text { 1. akusi (ngi)thi(na) } \\
\text { 2. akusi nguye(na)/akusiye/ } \\
\text { akusuye }\end{array}$ & $\begin{array}{l}\text { 1. akubi ngibo(na) } \\
\text { 2. akubi nguye(na) }\end{array}$ \\
\hline
\end{tabular}




\subsection{The binary opposition of stative versus inchoative with reference to copulatives}

The umbrella term implication is used by some linguists to refer to the binary opposition stative versus inchoative.

\subsubsection{The inchoative copulatives}

Southern Ndebele is typically Bantu in that it uses the copulative verb stem -ba to mark inchoativeness in copulatives, as is evident from example 1a below:

1a. Bona baba batjhumayeli.

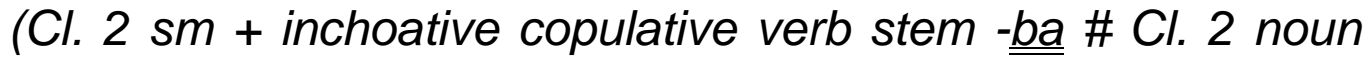
(without pre-prefix))

(They are becoming preachers.)

The copulative verb stem -ba takes the regular verbal derivational morphemes. In the negative of the present tense, for instance, the copulative verb stem -ba occurs as -bi. Consider example $1 \mathrm{~b}$ below:

1b. Bona ababi batjhumayeli.

(Neg. morpheme a $+\mathrm{Cl} .2 \mathrm{sm}+$ negative inchoative copulative verb stem -bi \# Cl. 2 noun (without pre-prefix))

(They are not becoming preachers.)

\subsubsection{The stative copulatives}

The affirmative form of the stative copulatives in Southern Ndebele is characterised by the absence of a verb stem. The phonological evidence supporting the postulation of an affirmative stative copulative verb stem *-li for Zulu is absent in Southern Ndebele. Hence it is posited that the affirmative form of the stative copulative in Southern Ndebele contains no (underlying) copulative verb stem.

In contrast to the affirmative stative copulative where no copulative verb stem occurs, the negative stative copulative verb stem -si occurs in all negative stative copulatives of Southern Ndebele. Consider for instance example (2b) below:

2a. Zizitja (< izitja).

(Reduplicated true prefix \# Cl. 8 noun (without pre-prefix)) (These are dishes.) 
2b. Azisi zizitja.

(Negative morph. a $+\mathrm{Cl} .8 \mathrm{sm}+$ negative copulative verb stem -si \# reduplicated true prefix $+\mathrm{Cl} .8$ noun (without pre-prefix)) (They are not dishes.)

\subsubsection{The copulative verb stems}

In Southern Ndebele, like the other Bantu languages, the binary opposition of inchoative versus stative is basically marked by the copulative verb stems. However, as already stated, no copulative verb stem occurs in the affirmative stative form. The table below reveals the binary opposition of implication, namely inchoative versus stative and the opposition of actuality, namely affirmative versus negative, as expressed by the copulative verb stems.

\begin{tabular}{|l|l|l|}
\hline $\begin{array}{l}\text { inchoative copulative } \\
\text { verb stem }\end{array}$ & $\begin{array}{l}\text { stative copulative } \\
\text { verb stem }\end{array}$ & \\
\hline -ba & $\varnothing$ & affirmative \\
\hline become & be & English glossary \\
\hline -bi & $-s i$ & negative \\
\hline
\end{tabular}

\section{The identificative copulatives of Southern Ndebele}

The identificative copulatives are those copulatives where the referent is identified in some way.

\subsection{The affirmative forms of the stative identificative copulative in the indicative mood with a noun as complement}

While the personal copulatives contain the particular subject agreement morpheme, the impersonal forms contain no subject morpheme. The impersonal forms are discussed here.

Impersonal identificative copulatives with a noun from any noun class as a complement (except classes 1a, 8, 9 and 10) are formed by using one of two basic strategies. The choice between these strategies is phonologically conditioned. If the noun root is 
monosyllabic the pre-prefix is omitted, while the true prefix ${ }^{3}$ is reduplicated. Consider the stative copulative forms listed below, derived from nouns from classes 3 and 5 respectively:

Class 3 noun: umukhwa (knife)

3a. Mumukhwa.

(It is a knife.)

Class 5 noun: ilihlo (eye)

3b. Lilihlo.

(It is an eye.)

However, if the noun root is polysyllabic, the pre-prefix is omitted while the tone on the true prefix changes from high to low, as is evident in the following examples from classes 4,6 and 7 respectively.

Class 4 noun: ímílambo (stream)

4a. Milambo.

(They are streams.)

Class 6 noun: ámáqanda (eggs)

4b. Màqanda.

(They are eggs.)

Class 7 noun: ísílonda (sore)

4c. Silonda.

(It is a sore.)

In the case of class 1a nouns, the identificative copulative particle $n g i$ is prefixed to the noun, thus:

Class 1a noun: ugogo (grandmother)

5. Ngugogo (< ngi \# ugogo).

(It is a grandmother.)

3 In languages that employ a pre-prefix, such as the Nguni languages, it is essential to distinguish between the pre-prefix and the true prefix. In the case of class 7 , for instance, the full prefix isi- comprises the pre-prefix $i$ - followed by the true prefix -si-. 
In Southern Ndebele (like Zulu) yi is prefixed to nouns in class 9 as identificative copulative particle to both mono- and polysyllabic noun roots, thus:

Class 9 nouns: into (thing) / inyathi (buffalo)

6a. Yinto (< yi \# into).

(It is a thing.)

6b. Yinyathi (< yi \# inyathi).

(It is a buffalo.)

If a noun from class 8 (with the noun class prefix izi-) or class 10 (with the noun class prefix izin-) with a monosyllabic root is used in a copulative as complement, the pre-prefix is omitted and the /CV/ part of the prefix (the true prefix) is reduplicated. Consider the examples below.

Class 8 noun: izitja (dishes)

7a. Zizitja.

(They are dishes.)

Class 10 noun: izinto (things)

7b. Zizinto.

(They are things.)

In Southern Ndebele (like Xhosa) polysyllabic noun roots from noun classes 8 and 10 take the contracted prefix iin- instead of izin-. In Southern Ndebele noun roots of these two noun classes (with the contracted prefix iin- or iim-) still prefix the /CV/ of the true prefix to these contracted prefixes in the copulative form. Consider examples $8 \mathrm{a}$ and $8 \mathrm{~b}$ with nouns from noun classes 8 and 10 respectively:

Class 8 noun: iinlonda (sores)

8a. Ziinlonda (< zi + iinlonda).

(They are sores.)

Class 10 noun: iinjasi (a coat)

8b. ziinjasi (< zi + iinjasi).

(They are coats.) 


\subsection{The negative forms of the personal and impersonal stative copulatives in the indicative mood with a noun as complement}

The negative forms of the personal and impersonal stative identificative copulatives in the indicative mood with nouns from any noun class as complement (except classes 1a and 9) have the following structure: negative morpheme a-, the particular negative subject morpheme (the impersonal subject morpheme $k u$-is used for the impersonal forms), the negative stative copulative verb stem -si, the identificative copulative form of the complementary noun. This implies that the pre-prefix is omitted and the true prefix is reduplicated with monosyllabic noun stems as in example 9a below, while in the case of polysyllabic noun stems, the pre-prefix is omitted, while the tone on the vowel of the true prefix changes to low as in example $9 \mathrm{~b}$ below.

9a. Le nto ayisi sisipho.

(This thing is not a present.)

9b. Awusi liqhegu.

(You are not an old man.)

If the complementary noun is a noun in class $1 \mathrm{a}$, the copulative has the following structure: negative morpheme $a-$, the particular negative subject morpheme (the impersonal subject morpheme kuis used for the impersonal forms), the negative stative copulative verb stem -si, the identificative copulative particle ngi, the complementary noun in class 1a. Consider example 10 below:

10. Loyo msana akasi nguMabhena $(<$ a- + -ka- + -si \# ngi \# uMabhena).

(That boy is not Mabhena.)

If the complementary noun is a noun in class 9 the copulative has the structure as explicated as follows: negative morpheme a-, the particular negative subject morpheme (the impersonal subject morpheme $k u$ - is used for the impersonal forms), the negative stative copulative verb stem -si, the identificative copulative particle $y i$, the complementary noun in class 9 . Consider example 11 below:

11. Isilwana lesi asisi yinja (< a- + -si- + -si \# yi \# inja).

(This animal is not a dog.) 
The personal and impersonal forms of the stative identificative copulative in the indicative mood, with a noun from each noun class as complement, are listed in the tables below.

\title{
4.3 Stative personal identificative copulatives in the indicative mood with a noun as complement: affirmative and negative forms
}

\author{
class noun \\ personal copulatives \\ 1 umuntu/umtsjhumayeli \\ pos: umumuntu; umtjhumayeli \\ (he/she is a human; he/she is a preacher) \\ neg: akasi mumuntu; akasi mtjhumayeli \\ (he/she is not a human; he/she is not a preacher) \\ 2 abantu/abatjhumayeli \\ pos: nibabantu; nibatjhumayeli \\ (you are humans; you are preachers) \\ neg: anisi babantu; anisi batjhumayeli \\ (you are not humans; you are not preachers) \\ 1a ugogo \\ pos: ungugogo \\ (you are a grandmother) \\ neg: awusi ngugogo \\ (you are not a grandmother) \\ 2a abomalume \\ pos: nibomalume \\ (you are an uncle and company) \\ neg: anisi bomalume \\ (you are not an uncle and company) \\ 3 umukhwa/umthetho \\ pos: imumukhwa; imthetho \\ (it (the thing) is a knife; it is a law/rule) \\ neg: ayisi mumukhwa; ayisi mthetho \\ (it (the thing) is a not a knife; it is not a law/rule) \\ $4 \quad$ imikhwa/imilambo \\ pos: zimimikhwa; zimilambo \\ (they (the things) are knives; they are streams) \\ neg: azisi mimikhwa; azisi milambo \\ (they (the things) are not knives; they are not \\ streams) \\ 5 ilihlo/iqhegu \\ pos: ililihlo; iliqhegu \\ (it (the thing) is an eye; it is an old man) \\ neg: ayisi lilihlo; ayisi liqhegu \\ (it (the thing) is not an eye; it is not an old man) \\ 6 amatje/amaqanda \\ pos: zimamatje; zimaqanda \\ (they (the things) are rocks; they are eggs) \\ neg: azisi mamatje; azisi maqanda \\ (they (the things) are not rocks; they are not \\ eggs)
}


class noun

7

isipho/isilonda

8 izitja/izoni

9

10

14

15 inja/ijasi

izinja/iinjasi

ubuso/ubukhokho

ukufa/ukuthunga

\section{personal copulatives}

pos: isisipho; isilonda (it (the thing) is a present; it is a sore) neg: ayisi sisipho; ayisi silonda (it (the thing) is not a present; it is not a sore)

pos: zizizitja; zizoni

(they (the things) are dishes; they are sinners) neg: azisi zizitja; azisi zizoni

(they (the things) are not dishes; they are not sinners)

pos: iyinja; iyijasi

(it (the thing) is a dog; it is a jacket)

neg: ayisi yinja; ayisi yijasi

(it (the thing) is not a dog; it is not a jacket)

pos: zizinja; ziziinjasi

(they (the things) are dogs; they are jackets)

neg: azisi zizinja; azisi ziinjasi

(they (the things) are not dogs; they are not jackets)

pos: ibubuso; ibukhokho

(it (the thing) is a face; it is ancestry)

neg: ayisi bubuso; ayisi bukhokho

(it (the thing) is not a face; it is not ancestry)

pos: ikukufa; ikuthunga

(it (the thing) is death; it is sewing)

neg: ayisi kukufa; ayisi kuthunga

(it (the thing) is not death; it is not sewing)

\subsection{Stative impersonal identificative copulatives in the indicative mood with a noun as complement: affirmative and negative patterns}

$\begin{array}{ll}\text { class } & \text { noun } \\ 1 & \text { umuntu/umtjhumayeli }\end{array}$

2

\section{impersonal copulatives}

pos: mumuntu; mtjhumayeli

(it is a human; it is a preacher)

neg: akusi mumuntu; akusi mtjhumayeli

(it is not a human; it is not a preacher)

pos: babantu; batjhumayeli

(they are humans; they are preachers)

neg: akusi babantu; akusi batjhumayeli

(they are not humans; they are not preachers) 


\begin{tabular}{|c|c|c|}
\hline class & noun & impersonal copulatives \\
\hline $1 a$ & ugogo & $\begin{array}{l}\text { pos: ngugogo } \\
\text { (it is a grandmother) } \\
\text { neg: akusi ngugogo } \\
\text { (it is not a grandmother) }\end{array}$ \\
\hline $2 a$ & abomalume & $\begin{array}{l}\text { pos: bomalume } \\
\text { (they are uncles / uncle and company) } \\
\text { neg: akusi bomalume } \\
\text { (they are not uncles / uncle and company) }\end{array}$ \\
\hline 3 & umukhwa/umthetho & $\begin{array}{l}\text { pos: mumukhwa; mthetho } \\
\text { (it is a knife; it is a law/rule) } \\
\text { neg: akusi mumukhwa; akusi mthetho } \\
\text { (it is not a knife; it is not a law/rule) }\end{array}$ \\
\hline 4 & imikhwa/imilambo & $\begin{array}{l}\text { pos: mimikhwa; milambo } \\
\text { (they are knives; they are streams/rivers) } \\
\text { akusi mimikhwa; akusi milambo } \\
\text { (it is not knives; it is not streams/rivers) }\end{array}$ \\
\hline 5 & ilihlo/iqhegu & $\begin{array}{l}\text { pos: lilihlo; liqhegu } \\
\text { (it is an eye; it is an old man) } \\
\text { neg: akusi lilihlo; akusi liqhegu } \\
\text { (it is not an eye; it is not an old man) }\end{array}$ \\
\hline 6 & amatje/amaqanda & $\begin{array}{l}\text { pos: mamatje; maqanda } \\
\text { (they are rocks/stones; they are eggs) } \\
\text { neg: akusi mamatje; akusi maqanda } \\
\text { (it is not rocks/stones; it is not eggs) }\end{array}$ \\
\hline 7 & isipho/isilonda & $\begin{array}{l}\text { pos: sisipho; silonda } \\
\text { (it is a gift; it is a sore) } \\
\text { neg: akusi sisipho; akusi silonda } \\
\text { (it is not a gift; it is not a sore) }\end{array}$ \\
\hline 8 & izitja/izoni & $\begin{array}{l}\text { pos: zizitja; zizoni } \\
\text { (they are dishes; they are sinners) } \\
\text { neg: akusi zizitja; akusi zizoni } \\
\text { (they are not dishes; they are not sinners) }\end{array}$ \\
\hline 9 & inja/ijasi & $\begin{array}{l}\text { pos: yinja; yijasi } \\
\text { (it is a dog; it is a jacket) } \\
\text { neg: akusi yinja; akusi yijasi } \\
\text { (it is not a dog; it is not a jacket) }\end{array}$ \\
\hline 10 & izinja/iinjasi & $\begin{array}{l}\text { pos: zizinja; ziinjasi } \\
\text { (they are dogs; they are jackets) } \\
\text { neg: akusi zizinja; akusi ziinjasi } \\
\text { (they are not dogs; they are not jackets) }\end{array}$ \\
\hline 14 & ubuso/ubukhokho & $\begin{array}{l}\text { pos: bubuso; bukhokho } \\
\text { (it is a face; it is ancestry) } \\
\text { neg: akusi bubuso; akusi bukhokho } \\
\text { (it is not a face; it is not ancestry) }\end{array}$ \\
\hline
\end{tabular}

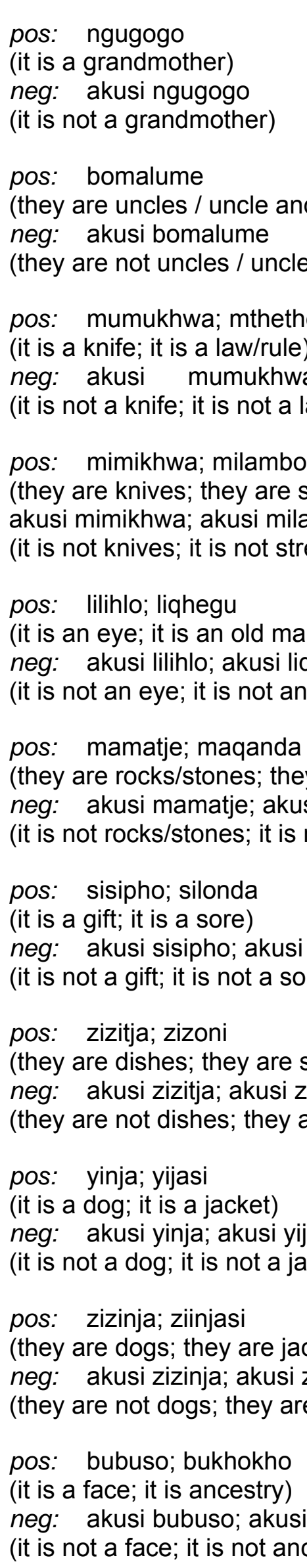


class

pronoun

15

ukufa/ukuthunga impersonal copulatives

pos: kukufa; kuthunga

(it is death; it is sewing)

neg: akusi kukufa; akusi kuthunga

(it is not death; it is not sewing)

\subsection{The patterns of the stative and inchoative forms of the identificative copulative in the indicative mood with a noun as complement}

The affirmative and negative patterns of the stative identificative copulatives in the indicative mood with a noun as complement can be summarised as follows:

\begin{tabular}{|c|c|}
\hline \multicolumn{2}{|c|}{ Stative copulative forms in the indicative mood } \\
\hline \multicolumn{2}{|c|}{ Personal forms } \\
\hline Affirmative & Negative \\
\hline $\begin{array}{l}\text { Umtjhumayeli } \\
\text { (<u- \# mtjhumayeli) } \\
\text { (you are a preacher) }\end{array}$ & $\begin{array}{l}\text { awusi mtjhumayeli } \\
\text { (< a-+-wu---si \# mtjumayeli) } \\
\text { (you are not a preacher) }\end{array}$ \\
\hline $\begin{array}{l}\text { Nibabantu } \\
\text { (< ni- \# ba+bantu) } \\
\text { (you are humans) }\end{array}$ & $\begin{array}{l}\text { anisi babantu } \\
\text { (< a-+-ni---si \# ba+bantu) } \\
\text { (you are not humans) }\end{array}$ \\
\hline $\begin{array}{l}\text { Ungugogo } \\
\text { (< u- \# ngi \# ugogo) } \\
\text { (you are a grandmother) }\end{array}$ & $\begin{array}{l}\text { awusi ngugogo } \\
\text { (< a-+-wu---si \# ngi \# ugogo) } \\
\text { (you are not a grandmother) }\end{array}$ \\
\hline $\begin{array}{l}\text { Siyinja } \\
\text { (< si- \# yi \# inja) } \\
\text { (it (the animal) is a dog) }\end{array}$ & $\begin{array}{l}\text { asisi yinja } \\
(<\text { a-+-si---si \# yi \# inja) } \\
\text { (it (the animal) is not a dog) }\end{array}$ \\
\hline \multicolumn{2}{|c|}{ Impersonal forms } \\
\hline Affirmative & Negative \\
\hline $\begin{array}{l}\text { Mthumayeli } \\
(<\text { umthumayeli) } \\
\text { (it is a preacher) }\end{array}$ & $\begin{array}{l}\text { akusi mthumayeli } \\
\text { (< a-+-ku-+-si \# mthumayeli) } \\
\text { (it is not a preacher) }\end{array}$ \\
\hline $\begin{array}{l}\text { Babantu } \\
\text { (< ba+bantu) } \\
\text { (it is humans) }\end{array}$ & $\begin{array}{l}\text { akusi babantu } \\
\text { (< a-+-ku-+-si \# ba+bantu) } \\
\text { (it is not humans) }\end{array}$ \\
\hline
\end{tabular}




\begin{tabular}{|l|l|}
\hline $\begin{array}{l}\text { Ngugogo } \\
\text { (< ngi \# ugogo) } \\
\text { (it is a grandmother) }\end{array}$ & $\begin{array}{l}\text { awusi ngugogo } \\
\text { (< a-+-ku-+-si \# ngi \# ugogo) } \\
\text { (it is not a grandmother) }\end{array}$ \\
\hline $\begin{array}{l}\text { Yinja } \\
(<\text { yi \# inja) } \\
\text { (it is a dog) }\end{array}$ & $\begin{array}{l}\text { akusi yinja } \\
\text { (< a-+-ku-+-si \# yi \# inja) } \\
\text { (it is not a dog) }\end{array}$ \\
\hline
\end{tabular}

The inchoative forms of the identificative copulative are similar to the stative forms except that the inchoative verb stem -ba occurs after the subject morpheme in the affirmative and $-b i$ in the negative forms. (The inchoative verb stems behave in most respects like any regular verb stem.) Consider the examples below.

\begin{tabular}{|c|c|}
\hline \multicolumn{2}{|c|}{ Inchoative copulative forms in the indicative mood } \\
\hline \multicolumn{2}{|c|}{ Personal forms } \\
\hline Affirmative & Negative \\
\hline $\begin{array}{l}\text { uba mtjhumayeli } \\
\text { (< u-+-ba \# mtjhumayeli) } \\
\text { (you become a preacher) }\end{array}$ & $\begin{array}{l}\text { awubi mtjhumayeli } \\
\text { (< a-+-wu-+-bi \# mtjumayeli) } \\
\text { (you are not becoming a preacher) }\end{array}$ \\
\hline $\begin{array}{l}\text { niba babantu } \\
(<\text { ni-+-ba \# ba+bantu) } \\
\text { (you are becoming humans) }\end{array}$ & $\begin{array}{l}\text { anibi babantu } \\
\text { (< a-+-ni-+-bi \# ba+bantu) } \\
\text { (you are not becoming humans) }\end{array}$ \\
\hline $\begin{array}{l}\text { uba ngugogo } \\
\text { (< u-+-ba \# ngi \# ugogo) } \\
\text { (you are becoming a grandmother) }\end{array}$ & $\begin{array}{l}\text { awubi ngugogo } \\
\text { (< a-+-wu-+-bi \# ngi \# ugogo) } \\
\text { (you are not becoming a } \\
\text { grandmother) }\end{array}$ \\
\hline $\begin{array}{l}\text { siba yinja } \\
\text { (< si-+-ba \# yi \# inja) } \\
\text { (it (the animal) is becoming a dog) }\end{array}$ & $\begin{array}{l}\text { asibi yinja } \\
(<\text { a-+-si-+-bi \# yi \# inja) } \\
\text { (it (the animal) is not becoming a } \\
\text { dog) }\end{array}$ \\
\hline \multicolumn{2}{|c|}{ Impersonal forms } \\
\hline Affirmative & Negative \\
\hline $\begin{array}{l}\text { kuba milambo } \\
(<\text { ku-+-ba \# milambo) } \\
\text { (it is becoming streams) }\end{array}$ & $\begin{array}{l}\text { akubi milambo } \\
\text { (< a-+-ku-+-bi \# milambo) } \\
\text { (it is not becoming streams) }\end{array}$ \\
\hline $\begin{array}{l}\text { kuba sisifo } \\
\text { (< ku-+-ba \# si+sifo) } \\
\text { (it is becoming a disease) }\end{array}$ & $\begin{array}{l}\text { akubi sisifo } \\
\text { (< a-+-ku-+-bi \# si+sifo) } \\
\text { (it is not becoming a disease) }\end{array}$ \\
\hline
\end{tabular}


kuba ngugogo

(< ku-+-ba \# ngi \# ugogo)

(it is becoming a grandmother)

kuba yinja

(< ku-+-ba \# yi \# inja)

(it is becoming a dog) akubi ngugogo

(< a-+-ku-+-bi \# ngi \# ugogo)

(it is not becoming a grandmother)

akubi yinja

(< a-+-ku-+-bi \# yi \# inja)

(it is not becoming a dog)

\subsection{The stative forms of the identificative copulative in the indicative mood with pronouns as complement}

In Southern Ndebele the identificative copulatives with an emphatic pronoun as complement are characterised by the use of the identificative copulative particle ngi for all classes. The basic patterns for the affirmative and negative of the stative forms are indicated below.

\subsubsection{Affirmative pattern of the identificative copulative in the indicative mood with a pronoun as complement}

\begin{tabular}{|l|l|l|l|l|}
\hline $\begin{array}{l}\text { subject } \\
\text { morpheme }\end{array}$ & $\begin{array}{l}\text { identificative } \\
\text { copulative } \\
\text { particle }\end{array}$ & $\begin{array}{l}\text { shortened } \\
\text { pronoun }\end{array}$ & $\begin{array}{l}\text { resultant } \\
\text { form }\end{array}$ & English glossary \\
\hline u- & ngi & so(na) & ungiso & (you are it) (cl 7) \\
\hline ba- & ngi & bo(na) & bangibo & (they are them) \\
\hline
\end{tabular}

\subsubsection{Negative pattern of the identificative copulative in the indicative mood with a pronoun as complement}

The forms below are the negative forms of the forms listed in the above table (4.2.1).

\begin{tabular}{|l|l|l|l|l|l|}
\hline $\begin{array}{l}\text { negative } \\
\text { morpheme }\end{array}$ & $\begin{array}{l}\text { negative } \\
\text { subject } \\
\text { morpheme }\end{array}$ & $\begin{array}{l}\text { negative } \\
\text { copulative } \\
\text { verb stem }\end{array}$ & $\begin{array}{l}\text { identificative } \\
\text { copulative } \\
\text { particle }\end{array}$ & $\begin{array}{l}\text { shortened } \\
\text { pronoun }\end{array}$ & $\begin{array}{l}\text { resultant } \\
\text { form }\end{array}$ \\
\hline a- & -wu- & - si & (ngi) & so(na) & $\begin{array}{l}\text { awusi } \\
\text { ngiso/awusiso }\end{array}$ \\
\hline a- & -ba- & - si & (ngi) & bo(na) & $\begin{array}{l}\text { abasi ngibo/ } \\
\text { abasibo }\end{array}$ \\
\hline
\end{tabular}


A comprehensive list of stative copulative forms, with emphatic pronouns for the individual noun classes as complement, are listed in the table below. The only difference between the personal and impersonal forms is that in the impersonal forms the subject morpheme $k u$ - is used.

\subsubsection{Stative personal and impersonal identificative copulatives in the indicative mood with an emphatic pronoun as complement}

\begin{tabular}{|c|c|c|}
\hline class & pronoun & identificative copulative \\
\hline $1 a$ & yena & $\begin{array}{l}\text { pos: unguye } \\
\text { (he/she is him/her) } \\
\text { neg: akasi nguye / akasuye } \\
\text { (he/she is not him/her) }\end{array}$ \\
\hline $2 a$ & bona & $\begin{array}{l}\text { pos: ningibo } \\
\text { (you (pl.) are them) } \\
\text { neg: anisi ngibo / asisibo } \\
\text { (you (pl.) are not them) }\end{array}$ \\
\hline 3 & wona & $\begin{array}{l}\text { pos: ingiwo } \\
\text { (it (class 9) is it) } \\
\text { neg: ayisi ngiwo / ayisiwo } \\
\text { (it (class 9) is not it) }\end{array}$ \\
\hline 4 & yona & $\begin{array}{l}\text { pos: zingiyo } \\
\text { (they (class 10) are them) } \\
\text { neg: ayisi ngiyo / ayisiyo } \\
\text { (they (class 10) are not them) }\end{array}$ \\
\hline 5 & Iona & $\begin{array}{l}\text { pos: kungilo } \\
\text { (it is it) } \\
\text { neg: akusi ngilo / akusilo } \\
\text { (it is not it) }\end{array}$ \\
\hline 6 & wona & $\begin{array}{l}\text { pos: ingiwo } \\
\text { (they (class 10) are them) } \\
\text { neg: ayisi ngiwo / ayisiwo } \\
\text { (they (class 10) are not them) }\end{array}$ \\
\hline 7 & sona & $\begin{array}{l}\text { pos: ingiso } \\
\text { (it (class 9) is it) } \\
\text { neg: ayisi ngiso / ayisiso } \\
\text { (it (class 9) is not it) }\end{array}$ \\
\hline 8 & zona & $\begin{array}{l}\text { pos: kungizo } \\
\text { (it is them) } \\
\text { neg: akusi ngizo / akusizo } \\
\text { (it is not them) }\end{array}$ \\
\hline
\end{tabular}




\begin{tabular}{|c|c|c|}
\hline class & pronoun & identificative copulative \\
\hline 9 & yona & $\begin{array}{l}\text { pos: ingiyo } \\
\text { (it (class } 9 \text { ) is it) } \\
\text { neg: ayisi ngiyo / ayisiyo } \\
\text { (it (class } 9 \text { ) is not it) }\end{array}$ \\
\hline 10 & zona & $\begin{array}{l}\text { pos: kungizo } \\
\text { (it is them) } \\
\text { neg: akusi ngizo / akusizo } \\
\text { (it is not them) }\end{array}$ \\
\hline 14 & bona & $\begin{array}{l}\text { pos: kungibo } \\
\text { (it is it) } \\
\text { neg: akusi ngibo / akusibo } \\
\text { (it is not it) }\end{array}$ \\
\hline 15 & khona & $\begin{array}{l}\text { pos: kungikho } \\
\text { (it is it) } \\
\text { neg: akusi ngikho / akusikho } \\
\text { (it is not it) }\end{array}$ \\
\hline
\end{tabular}

The identificative copulative particle ngi occurs before all demonstrative pronouns as well. Consider example 12 below.

12. Ngilezo (< ngi \# lezo) iinkuni eziberegiswako na kubaswa umlilo.

(It is that firewood that is used when a fire is made.)

\subsection{The identificative copulative in the different moods}

The only differences between the identificative copulative in the indicative mood and the moods other than the indicative are that the appropriate subject morphemes for that particular mood are used, while, in the negative, the particular subject morpheme is followed by the negative morpheme -nga- instead of being preceded by the negative morpheme $a-$.

Identificative copulative forms of the situative mood are supplied as examples of these copulatives in a mood other than the indicative mood. 


\subsubsection{The stative forms of the identificative copulative in the situative mood}

\begin{tabular}{|l|l|}
\hline Affirmative & Negative \\
\hline $\begin{array}{l}\text { (nagade) uyikosi ... } \\
((\text { if) you are a king ...) }\end{array}$ & $\begin{array}{l}\text { (nagade) ungasi yikosi ... } \\
(\text { (if) you are not a king ...) }\end{array}$ \\
\hline $\begin{array}{l}\text { (nagade) amumuntu ... } \\
((\text { if) he/she is a human ...) }\end{array}$ & $\begin{array}{l}\text { (nagade) angasi mumuntu ... } \\
\text { ((if) he/she is not a human ...) }\end{array}$ \\
\hline
\end{tabular}

\subsubsection{The inchoative forms of the identificative copulative in the situative mood}

\begin{tabular}{|l|l|}
\hline Affirmative & Negative \\
\hline $\begin{array}{l}\text { (nagade) uba yikosi ... } \\
\text { ((if) you become a king ...) }\end{array}$ & $\begin{array}{l}\text { (nagade) ungabi yikosi ... } \\
\text { ((if) you do not become a king ...) }\end{array}$ \\
\hline $\begin{array}{l}\text { (nagade) aba mumuntu .... } \\
\text { ((if) he/she becomes a human ...) }\end{array}$ & $\begin{array}{l}\text { (nagade) angabi mumuntu ... } \\
\text { ((if) he/she does not become a human ...) }\end{array}$ \\
\hline
\end{tabular}

\section{Comparison between the identificative copulatives of Southern Ndebele and Zulu}

In Southern Ndebele the basic strategy for the formation of the identificative copulatives with nouns as complement is to omit the pre-prefix and to reduplicate the /CV/ of the true prefix (if the noun root is monosyllabic) or to omit the pre-prefix and lower the tone on the true prefix (if the noun root is polysyllabic). This strategy is also prominent in Xhosa. In those instances where a noun from noun class $1 \mathrm{a}$ is used as complement, an identificative copulative particle ngi occurs before the noun, while in those instances where a noun from noun class 9 is used as complement, an identificative copulative particle yi occurs before it.

In Zulu, however, the basic strategy is to use the identificative copulative particle ngi (or yi which has developed from ngi) before all nouns. The identificative copulative particle ngi is used before nouns commencing with the vowels $a, u$ and $o$, while $y i$ is used before nouns commencing with the vowel $i$. 
In Southern Ndebele the identificative copulative particle ngi is used before all pronouns (except those of 2 nd person singular and class 1 and 1a where ngi becomes ngu. Consider the forms nguwe and nguye in this regard).

However, in Zulu the identificative copulative particle yi is used before all pronouns (except those of 2nd person singular and classes 1 and 1a where, like Southern Ndebele, the identificative copulative particle ngi is used). In the latter instances the identificative copulative particle ngi becomes ngu in Zulu as well, thus resulting in the forms nguwe and nguye.

\subsection{The postulation of the identificative copulative particle of Zulu as $n g(i)$}

Grammarians are not in agreement as far as the postulation of the form of the identificative copulative particle of Zulu is concerned. This form has been postulated as nga, ngu, ng and $n g i$.

Van Eeden (1956:397) contends that this copula is nga. However, according to the normal phonological rules of Zulu /a $+u>0$ /. Hence, one would expect the vowel coalescence in an example such as u-nga-uSabela to result in the form ungoSabela (you are Sabela). The resultant form is, however, unguSabela (you are Sabela). Hence, Van Eeden's postulation cannot be supported.

On the other hand, Poulos and Msimang (1998:356) postulate the identificative copula as ngu. Again, the general phonological rules for vowel coalescence in Zulu yield a problem since $/ u+a>w a$, yet the Zulu form of the phrase (they are our boys) is not *bangwabafana (< ba-ngu-abafana) bakithi but bangabafana bakithi. This postulation is therefore also rejected.

Doke (1981:216), Ziervogel, Louw and Taljaard (1985:103) as well as Taljaard and Bosch (1988:91) identify the identificative copula as being $n g$. No Zulu word or morpheme ends on a consonant (except a few ideophones with a paranormal phonological structure). The postulation of the identificative copulative particle as $n g$ is thus also rejected.

Posthumus (1978:65 and 1988:63) is the only contemporary scholar who postulates the identificative copulative particle of Zulu as ngi. This postulation is supported by language internal as well as language external evidence. 
The language internal evidence in support of the postulation of the identificative copulative particle as ngi is the following:

- The postulation of the identificative copulative particle as ngi is the only one that does not yield contradictions in terms of the normal phonological rules of Zulu for vowel coalescence.

$$
\begin{array}{cc}
\text { ngi + u.. }>\text { ngu.. } & \text { unguSabela (< u- \# ngi \# uSabela) (you are Sabela) } \\
\text { ngi + a.. }>\text { nga.. } & \text { bangabafana (< ba- \# ngi \# abafana) (they are boys) } \\
\text { ngi + o.. > ngo.. } & \text { bangomalume (< ba- \# ngi \# omalume) (they are uncles) }
\end{array}
$$

- The variant identificative copulative particle yi of Zulu (that occurs before nouns commencing with the vowel $i$ and the majority of pronouns) seems to be a later development judging from forms such as a si ngimi (It is not me) supplied by Grout (1859:104) and Wanger (1917:644) and ngiti (it is us) noted by Wanger (1917:604). These forms occur as akusimina/akuyimi (it is not me) and yithi (it is us) respectively in present-day Zulu.

The language external evidence in support of the postulation of the identificative copulative particle as ngi is the following:

- The identificative copulative particle in the Bantu languages is generally identical in form to the subject morpheme of the first person singular. In this regard one can thus expect the identificative copulative particle of Zulu to occur as ngi.

- Meinhof (1948:153) actually states that the identificative copula of Zulu is ngi. He says:

In vielen Sprachen wird ein besonderes Wort als pronominale Kopula für alle Klassen gebraucht, im Suahili: ni, ... Zulu: ngi, ...

- The identificative copulative particle is postulated as a development from Ur Bantu ni $+i$ (resulting in the form ngi for Zulu) by Van Wyk (1953:21).

- The Southern Ndebele data support the postulation of the identificative copulative particle as ngi. (Note that in Southern Ndebele the identificative copulative particle occurs as ngi before nouns of class $1 \mathrm{a}$ and before all pronouns. Since Southern Ndebele and Zulu are closely related languages, one can expect 
these languages to have the same underlying identificative copulative particle). It is thus postulated that, diachronically, Southern Ndebele and Zulu had the same form for the identificative copulative particle, namely ngi.

\subsection{Significance of the occurrence of the negative copulative verb stem -si in Southern Ndebele}

The host of linguists, inter alia Meinhof (1948); Van Wyk (1953); Van Eeden (1956); De Clercq (1958); Lanham (1971); Von Staden (1973); Wilkes (1974) and Posthumus (1978) and (1988) who have postulated an underlying stative copulative verb stem -*li (and *-si in the negative) for Zulu have either not motivated the postulation or have based their postulation on the presence of these copulative verb stems in languages such as the Sotho languages.

One scholar who rejects such a postulation outright is Cope (1963:83), who says:

Again it is sometimes suggested that the contraction may be /nge/<*ngali, but again there is no evidence in Zulu.

For a detailed discussion of the justification for the postulation of an underlying stative copulative verb stem in Zulu, cf. Posthumus (1978:38-47 and 1988:62).

Although Nkabinde supports the postulation of an underlying copulative verb stem *-li in the affirmative forms of the stative identificative copulatives, he rejects the existence of an underlying copulative verb stem in the negative forms of the copulative. He (Nkabinde, 1986:58) maintains:

Unlike Posthumus (1980) we do not find justification for postulating a negative form of the lexical $l i$ in the deep structure.

It transpires from the examples cited by Gauton (2002:357) that she too does not recognise the existence of a negative copulative verb stem -si. In the analysis of her examples she postulates the underlying negative stative copulative verb stem as *-li.

The overwhelming evidence from a large number of Bantu languages where the negative stative copulative verb stem occurs as -si and the fact that this copulative verb stem actually occurs in examples such as 13 cited below, rule out the possibility of the negative stative copulative verb stem being *-li in Zulu. 
The stative copulative verb stem generally has a very limited occurrence in those Bantu languages where it occurs in the surface structure. One of the strongest arguments used by linguists for the postulation of an underlying copulative verb stem *-li (and -si in the negative) for the stative copulatives of Zulu is based on comparative arguments. In this regard reference is generally made to the Sotho languages. However, in contrast to the Sotho languages, the negative copulative verb stem -si of Southern Ndebele occurs in all the subcategories of the stative copulatives (identificative, associative, descriptive and locative forms) and in all the moods. Southern Ndebele (being a language closely related to Zulu) thus offers the strongest language external evidence, on the comparative level, for the postulation of the negative stative copulative verb stem -si for Zulu.

Another consideration for the postulation of an underlying negative stative copulative verb stem -si in Zulu is the remnant form with -si occurring in a very limited number of cases in the identificative copulative as an alternative form. Consider the first three variants in example 13 below in this regard:

13. Angisinguye/Angisiye/Angisuye/Anginguye uThemba.

(Negative morph. a - 1st p. sing. sm ngi-negative copulative verb stem -si (\# identificative copulative particle (ngi)) \# Cl. 1 shortened emphatic pronoun ye(na) $(<u-e-n a)$

(I am not him, Themba.)

Further language internal support for such a postulation for Zulu is given by Posthumus (1988:62). He argues that the phonological change of the non-indicative negative morpheme from -nga- to -ngeand the progressive aspectual morpheme from -sa- to -se- (in the stative copulatives) is due to the influence of the vowel [i] of the omitted copulative verb stems (*-li for the positive forms or ${ }^{*}$-si for the negative forms respectively). Consider the Zulu examples 14 and 15 below:

14. Umfana ongeyindoda $\left(<0-\right.$ ngă $-{ }_{*}$ si \# y(i) \# indoda) ... (The boy who is not a man ...) 15. Umfana oseyingane $\left(<0-\right.$ sa $-{ }^{*} \sharp \#$ y(i) \# ingane) $\ldots$
(The boy who is still a child ...)

When both the negative morpheme -nga- and the progressive aspectual morpheme -sa- appear in a non-inchoative identificative 
copulative, only the progressive aspectual morpheme -sa- changes to -se- while the negative morpheme remains -nga-. This is due to the syntagma of the morphemes. The omitted vowel /i/ of the copulative verb stem -si will coalesce with the immediately preceding vowel $/ a /$, of - sa- to become $/ e /$, while the vowel $/ a /$ of -nga- will not coalesce. Consider example 16 below.

16. Umfana ongaseyingane (<o-nga - sa - *si \# y(i) \# ingane) ... (The boy who is no longer a child ...)

The occurrence of the non-indicative negative morpheme as -nga-in the stative copulative forms of Southern Ndebele, as opposed to the negative morpheme -nge- of Zulu, can be explained in view of the fact that the copulative verb stem -si is not omitted in this Southern Ndebele and hence no vowel coalescence $/ a+i>e /$ takes place as is the case in Zulu. (Consider the explanation of the vowel coalescence in example 16 above.)

The Southern Ndebele data offer the most systematic evidence (on the comparative level) of all the languages in the South-Eastern Bantu language zone for the postulation of an underlying stative copulative verb stem -si in the negative copulative forms of Zulu.

\section{List of references}

COPE, A.T. 1963. Nomino-verbal constructions in Zulu. London: Luzac. (African Language Studies, IV.)

DE CLERCQ, J. 1958. Die kopulatief of nie-verbale predikaat in Nguni en Sotho: met besondere verwysing na Zulu en Suid-Sotho. Stellenbosch: Universiteit van Stellenbosch. (M.A.-verhandeling.)

DOKE C.M. 1986. Textbook of Zulu grammar. 6th ed. Cape Town: Maskew Miller Longman.

GAUTON, R. 2002. A critique of the Dokean approach towards the lexical classes "adjective", "relative" and "enumerative" in Zulu. Journal for Language Teaching, 36(3 \& 4):347-364.

GROUT, L. 1859. The isiZulu: a grammar of the Zulu language. Pietermaritzburg: May \& Davis.

LANHAM, L.W. 1971. The noun as the deep-structure source for Nguni adjectives and relatives. African Studies, 30(3 \& 4):299-312.

LOMBARD, D.P., VAN WYK, E.B. \& MOKGOKONG, P.C. 1985. Introduction to the grammar of Northern Sotho. Pretoria: Van Schaik.

LONGMAN CONCISE ENGLISH DICTIONARY. 1987. Essex: Longman Group.

MEINHOF, C. 1948. Grundzüge einer vergleichenden Grammatik der Bantusprachen. 2. Aufl. Hamburg: Eckardt \& Messtorf.

NKABINDE, A.C. 1986. An introduction to Zulu syntax. Pretoria: Acacia.

OXFORD ADVANCED LEARNER'S DICTIONARY. 1995. Oxford: Oxford University Press. 
PEI, M.A. \& GAYNOR, F. 1954. A dictionary of linguistics. New York: Philosophical Library.

POSTHUMUS, L.C. 1978. Die kopulatiewe in Zulu met verwysing na ander Bantoetale. Bloemfontein: UOVS. (M.A.-verhandeling.)

POSTHUMUS, L.C. 1988. Identifying copulatives in Zulu and Southern Sotho. South African Journal of African Languages, 8(2):61-64.

POULOS, G. \& MSIMANG, C.T. 1998. A linguistic analysis of Zulu. Pretoria: Via Afrika.

TALJAARD, P.C. \& BOSCH, S.E. 1988. Handbook of IsiZulu. Pretoria: Van Schaik.

THE COLLINS PAPERBACK ENGLISH DICTIONARY. 1986. Glasgow: William Collins.

VAN EEDEN, B.I.C. 1956. Zoeloe-grammatika. Stellenbosch: Universiteit van Stellenbosch.

VAN WYK, E.B. 1953. Die kopulatiewe van Noord-Sotho. Pretoria: Universiteit van Pretoria. (M.A.-verhandeling.)

VAN WYK, E.B. 1958. Woordverdeling in Noord-Sotho en Zoeloe. Pretoria: Universiteit van Pretoria. (Proefskrif.)

VAN WYK, E.B. 1968. Notes on word autonomy. Lingua, 21:543-557.

VON STADEN, P.M.S. 1973. Adjektiewe en relatiefstamme in Zulu as soortlike naamwoorde. Limi, 1(1):20-25.

WANGER, P.W. 1917. Konversations-grammatik der Zulu-Sprache. Mariannhill: St Thomas Aquins.

WELMERS, W.E. 1973. African language structures. Berkley: University of California Press.

WILKES, A. 1974. Oor die sogenaamde eksklusiewe kwantitatiewe van Zulu: studies in bantoetale. Pretoria: University of Pretoria.

ZIERVOGEL, D., LOUW, J.A. \& TALJAARD, P.C. 1985. A handbook of the Zulu language. Pretoria: Van Schaik.

\section{Key concepts:}

copula: the identificative copulatives in Southern Ndebele and Zulu diachronic postulation: the stative copulative verb stem -si identificative copulatives: comparison Southern Ndebele vs Zulu identificative copulatives: Southern Ndebele

\section{Kernbegrippe:}

diachroniese postulering: statiewe kopulatiewe werkwoordstam -si identifiserende kopulatiewe van Suid-Ndebele identifiserende kopulatiewe: vergelyking Suid-Ndebele vs Zulu kopula: die identifiserende kopulatiewe in Suid-Ndebele en Zulu 